\title{
Sharing an integral Christian worldview with a younger generation: Why and how should it be done and received?
}

Author:
Bennie J. van der Walt
Affiliation:
School of Philosophy,
North-West University,
Potchefstroom Campus,
South Africa
Corresponding author:
Bennie van der Walt,
benniejvanderwalt@gmail.
com
Dates:
Received: 15 Feb. 2017
Accepted: 03 May 2017
Published: 26 June 2017
code with your
How to cite this article:
Van der Walt, B., 2017,
to read online.
'Sharing an integral Christian
worldview with a younger
generation: Why and how
should it be done and
received?', In die Skriflig
51(1), a2245. https://doi.
org/10.4102/ids.v51i1.2245
Copyright:
(c) 2017. The Authors.
Licensee: AOSIS. This work
is licensed under the
Creative Commons
Attribution License.

This investigation discusses the question how an older generation should transfer to or share their own worldview with a younger generation. For various reasons this has become a problem today. One is the inability of some of the old guard to share their perspective on and way of life with the youth. Another factor is that the Christian youth of today is strongly influenced by contemporary cultural tendencies, often incompatible with a biblically based worldview. The question how a worldview should be transferred as well as how it should be received is of equal and crucial importance to ensure that an age-old, valuable tradition does not become the living worldview of the dead and the dead worldview of the living.

Therefore, answers to the following questions should be found: (1) What is the essence of such a worldview to be shared? (2) Why should it be shared? (3) How should it not be done? (4) What are the prerequisites for effective sharing? (5) What are the typical characteristics of the young receivers, the group today called Generation $\mathrm{Y}, \mathrm{Me}$, or the Millennials (those born between about 1980-2000)? (6) How should this group of emerging adults receive such a heritage?

The abstract above mentions the six questions to be answered by both the older and younger generation when they seriously try to share a Christian worldview. What follows is an attempt to provide answers to these problems.

\section{What do we want to share?}

The answer on this question is: an integral Christian worldview. It is taken for granted here that the adjective 'Christian' refers to the Person every Christian intends to follow. In everything one thinks and does one has to reflect the image (words and deeds) of Jesus Christ, one's Saviour but also one's Model. His identity should determine that of a Christian. Here the focus will be on the meaning of the noun, worldview. ${ }^{1}$

\section{Multi-dimensional}

According to a rationalistic viewpoint, a worldview will be something merely abstract, logical and theoretical. However, this viewpoint is no longer accepted. ${ }^{2}$ A genuine biblically based worldview is not something merely of the head (orthodoxy), or of the hand (orthopraxis), or of the heart only (mysticism).

According to Van der Walt (2008:6) a worldview is something human; the ideal is that one's whole being should be involved. A worldview should therefore be integral, comprehensive, including all the dimensions of life - it is a multi-dimensional, religiously directed cosmoscope. It includes, apart from the logical, also the emotional, historical, lingual, social (communal), economic, aesthetic, juridical, ethical and confessional (faith) aspects of being human. If we reduce it to any one of these, we have a one-sided, thin worldview.

An additional problem amongst the present generation is that through especially the electronic media they are exposed to and confronted with a variety of sometimes even conflicting worldviews. Therefore they tend to adhere to a mix of worldviews, to a pluralistic outlook (cf. 'A pluralistic outlook' below) and consequently experience difficulty to integrate these different impulses from outside. 
Perhaps one should distinguish between a worldview for, indicating the normative side of a worldview, and a worldview of, which refers to a personal appropriation and use of such a worldview within a changed context.

Two facets of a worldview are of special importance for this investigation, viz. the developmental and historical. The way a worldview is lived changes from one stage of a person's lifespan to another and from one historical period to the next. Since one's Christian worldview will differ from one developmental level to another (during childhood, youth, adulthood, middle years and old age) it cannot in the first instance simply be transferred by an older person to a younger one, or simply be inherited by a younger person or group. Secondly, since any worldview changes across historical time, different generations will have to respond to different cultural contexts to endorse a relevant, contemporary and living worldview.

Acknowledging these two facets of a worldview makes this process comprehensible and it can foster better intergenerational communication. If not handled correctly, it may also cause serious generation gaps and even conflicts.

\section{Answers to a way of life}

Following from the above, a worldview is not only a view of the world, but a way of life in the world. It not only tells one what is (the factual state of affairs), but also what ought to be done (the normative direction to be taken) in order to be able to walk the way.

For a worldview to be a way of life one continuously has to answer many vital questions like the following: What is real? Is there really a God or gods? Are there real guidelines for life, or are they simply human constructions, figments? Where can I find a dependable light to guide me through this confusing and sometimes dark world? What can be the source of all the abnormalities, suffering and evil? Who am I really, and what does it mean to be a human being? What should I be doing here? Do I have a task, any responsibility? Where am I going, and what will happen to me the day I die? What does my relationship to others imply? Should I try to change this world, and if so, how should it be done?

Bavinck (1981:111, 112) writes that in all these worldview questions the central question is: Who am I, a small, mortal speck in the midst of powerful realities with which I am confronted and with which my life is most intimately related? One's answers to this question also decide one's identity. $\mathrm{He}$ summarises these five realities as follows:

What am I against the norm, the strange phenomenon that has authority over me? What am I in my life that speeds on and on a doer or a victim? What am I in the face of the remarkable feeling that overwhelms me sometimes, the feeling that everything must be changed and that things are not right as they are? What am I against that very mysterious background of existence, the divine powers? (p. 111-112)
Bavinck also writes that the answers given to these existential questions are interconnected. Even the so-called non-religious person has to answer them not only in times of crises, but in the course of everyday life (cf. Bavinck 2013:145 ff.). Even a Christian worldview will never be able to provide final answers to these deep questions. It can, nevertheless, equip one with worthwhile directions. The answers to these fundamental worldview questions always have practical implications. The way we see life determines how we walk through life. If one's answer to the first question above is that there is no God providing direction for life, one has to find it on one's own as best as possible. The same will apply if (as the answer to question two) one does not recognise any revelation outside oneself. Moreover, if one's answer to the fifth question is that one does not have a task and responsibility, why would one get out of bed every morning?

Summarised, a worldview contains both a descriptive or structural element of how the world - and oneself - looks or is, and a normative or directional side of how it ought to be. This last facet is evident as will be seen from the following discussion.

\section{Based on religious commitment}

Any worldview is based on deep religious convictions. Many of the characteristics which Walter (1979:10-11) ascribes to religion are therefore also applicable to a worldview. A worldview is something of ultimate concern. It provides its adherents with a validated place in the scheme of things, relates them to the rest of an ordered world. It injects meaning into one's life, enabling one to endure suffering, evil and death. It integrates both the individual and society. In summary it provides an own identity and a home in the vast universe. In the rest of his book, Walter gives many examples of the homelessness of contemporary Western mankind. As will be seen (see 'Homelessness' below), especially today's younger generation is confronted by such homelessness or directionlessness.

\section{A history or tradition}

Every worldview has its own story or history. The Christian-reformational worldview is not a recent fad, a fly-by-night. This tradition originated in the fourth century AD with Augustine (cf. Oden 2007). It was revived in the sixteenth century Reformation and the Reveille during the nineteenth century with inter alia Groen van Prinsterer. Abraham Kuyper (cf. Heslam 1998) and Herman Bavinck (cf. Bavinck 1913) in the twentieth century, elaborated upon this worldview. A Christian-reformational philosophy built on it was developed by Dirk Vollenhoven and Herman Dooyeweerd in the Netherlands and Hendrik Stoker in South Africa with many followers the world over. ${ }^{3}$

3.Two recent books covering this history are those of Bartholomew and Goheen (2013) and Hengstmen (2015); or consult the webste allofliferedeemed. The (2013) and Hengstmenge (2015); or consult the website allofliferedeemed. The history of a Christian worldview in our own country is reflected in a four-volum bibliography of 1555 pages (cf. Van der Walt ed. 1980). For an overview of the global presence of Christian-reformational scholarship, cf. Van der Walt (2010:127-151). 
As worldview storytellers by nature, human beings have something to say. When you tell your story, you also want to be listened to. It is terrible either not to be heard or not to listen to someone speaking - both ways negate a basic human need. What we say and how we respond affect us deeply.

Does our older generation still speak, speak clearly and enthusiastically it's Christian worldview, or have they become a silent generation? Is their worldview story perhaps locked in scholarly journals? Is the younger generation willing to listen? Perhaps both groups have to learn to listen and listen to learn.

\section{Neither conservative, nor progressive should be the norm}

Often a younger generation regards themselves as progressive, viewing the old guard as conservative traditionalists. The younger ones may say the older people, who think they possess the truth of a correct worldview, are the problem, while the younger progressive generation are the solution. Vice versa, older people like to remember the 'good old times' and want to convince people to maintain the past as far as possible against an orientation toward the future. (According to the General Difference Chart mentioned in footnote 8, I would, according to my age, be regarded a traditionalist!)

According to Vollenhoven $(2005: 11,12)$ the choice between conservative and progressive should be viewed as a false dilemma by Christians. It is not only an irony that during the course of time a position, initially taken to be progressive, will appear to be rather conservative. The problem is that the opposition, 'conservative versus progressive' does not provide a sound criterion for determining what is good and what is evil in either the past or present.

Keller (2008:51) agrees: 'The gospel of Jesus is not ... conservatism or liberalism. Nor is it something halfway along a spectrum between two poles - it is something else altogether.'

Also in the case of worldviews one should apply the norms of the gospel, above and outside the conservative and progressive dilemma, to judge both of them.

\section{A Christian worldview is fallible and should continuously be renewed}

A Christian worldview tradition is not immune against all kinds of derailments. It can and has often deteriorated into a mere intellectual system, a totalitarian, oppressive ideology; it can be misused for the influence and power of a specific group; it can lose biblical inspiration and even replace one's relationship with God.

No one has the right to attach to his worldview the qualification, Christian, if in even the smallest degree, it contains elements of disregarding God's command to love Him, our fellow humans and the rest of his creation.
Therefore, since we are sinful humans, a worldview story cannot always be retold in the same way. A genuine reformational worldview itself has to be reformed continuously. Never swear by the words of a human being! Every generation of Christians have to discern anew between what is good, less good and even wrong. In this regard the age-old dualism of secular-sacred should be rejected. According to such a tworealm theory of nature-supernature the natural sphere is depreciated, even regarded as sinful, while the supernatural domain (of grace) is viewed as inherently good and therefore over-emphasised.

Wolters (2005) wants this dualistic worldview to be replaced by an integral biblical one which distinguishes between structure and direction. He (1981) writes:

The Bible simply accepts, as a point of departure, that every creature of God is [structurally] good, and that sin and salvation are matters of opposing direction, not of evil and good sectors of the created order. All aspects of created life and reality are in principle equally good, and all are in principle equally subject to perversion and renewal. (p. 10-11; for detail cf. Wolters 2005)

In spite of all these reservations a Christian worldview is indispensable for a full and active Christian life. 'Can there be anything worse than losing your eyesight?', a blind Christian asked. 'Yes, losing your vision', St. Anthony replied.

Now a second question has to be answered.

\section{Why should a worldview be shared?}

Older people naturally believe that they have to share their vast wisdom with their descendants. However, there are at least four principial reasons for doing so.

\section{Four basic reasons}

Firstly, a Christian worldview should be regarded as a gift. No one owns it; its basics are given by God in his revelation. Therefore one has an obligation to share it with everyone. In Deuteronomy 6:5-9, God reminds his people of this task; also in Psalm 78:1-7 it is accepted as a duty.

Secondly, the Christian worldview is a prophetic worldview. God's Word requires that Christians are not only to serve Him in the offices of priests and kings, but also as prophets. They have to be professors, proclaimers, and witnesses.

Thirdly, sharing should be done out of love for the receivers. In addition, when you share, you do not part with what you give, you possess it in a deeper and richer way yourself.

A fourth reason is the inseparability of past, present and future. History takes all people forward in its movement. Whether one likes it or not, one carries the past with you. Even if one takes leave of the past, it keeps speaking to you. No one starts life with a clean slate. Often children and the youth are the report cards about their parents and teachers. Human beings become really mature and independent and see their own 
possibilities for the future distinctly when they discover how much they have received from their parents - in particular on the points where they differ from their view and way of life (cf. Van der Hoeven 1980:13).

Christians therefore have a responsibility regarding those who preceded them. If today they live correctly, they can provide sense to the sacrifices and even suffering of their predecessors on their behalf. Or they can correct what their ancestry has done wrongly. At the same time, old and young are co-creators of the future. The worth of their lives will depend on the quality of their heritage to future generations.

\section{Younger Christians today badly need a Christian worldview}

Apart from these basic reasons, one has to share one's Christian perspective on life, since the younger generation need it. Their numbers are also increasing rapidly. Estimates indicate that at about 2030 the percentage of younger people as part of the entire South African population will be the highest in the world.

Firstly, they are in need of a worldview because of the specific stage of life. If it is not shared with them during their emerging adulthood, it will be very difficult or even impossible to try to do so later.

Secondly, the present cultural and educational confusion demands our sharing. Bonzo and Stevens (ed. 2009) explains:

Students inhabit a phantasmagoria theatre of frantic media images, raw emotion, and powerful appeals that undermine the self to make the sale. In most cases their education at home has provided them with few moral concepts, let alone critical apparatus to respond to this video arcade of the soul ... (p. 65)

Therefore a Christian worldview is needed:

A worldview grants students a life-saving capacity to respond sensibly to the commercially funded circus they encounter every day with its incessant in-your-face sexual posturing, its lures and lies, and its lunatic substituting of careless intimacy for love and shameless self-exposure for emotional authenticity ... To talk about worldview in the classroom ... that takes students' lived experience seriously, can be to create an oasis in a desperate, bewildering desert. (p. 65)

Garber (1996) agrees:

The opportunity to talk about their worldviews ... has for many graduates ... been perhaps the most powerful, informative and life-shaping educational memory that they have taken away with them into what is referred to as the real world. (p. 66)

Most of the 'producers' and 'products' of education today do not raise why questions but merely how one should do something. Neither do they ask according to what norms it should be done or see work as a calling. Students will say: Teach me marketable skills, how to become a moneymaking machine. Give me only the facts, tools and techniques - all the rest is irrelevant. Such an attitude can only lead to an empty, meaningless life.
Thirdly, our secular age is not religiously empty at all. We live in a polytheistic age, abounding with all kinds of new idols. Young people can easily be captivated by their seductive, misleading powers. ${ }^{4}$

The next (third) question is to be answered.

\section{How should a worldview not be shared?}

This research is limited to the sharing of a Christian worldview to Christians amongst the younger ones. (How to reach the many unconverted is a different issue.) The approach will firstly be to contrast how one should not share, with how it should be done correctly. The how not or pitfalls can best be explained by way of the following metaphors, a tyrant, a merchant, and a midwife (cf. Volf 2011:106-108).

\section{Not as a tyrant or demagogue}

He who really wants to share should not be a tyrant who prescribes or imposes anything - especially not a worldview on someone else. A worldview will not get footing in younger persons' lives by forcing or manipulating them to embrace it. The giver has to respect the receivers and the limits of what they are able and willing to accept.

God places a Christian worldview in our hands to be used out of love for God and the well-being of our fellow humans and the rest of creation. Because of our sinfulness, we are often inclined to see this power as a power under our control. Then it deteriorates into coercive power, an ideology, not a power derived from God's revelation and his Spirit to empower, to bring healing and direction in others' lives. $^{5}$

This implies that one cannot grab emerging adults by the scuffs of their necks and compel them to accept and live in accordance with one's own worldview. Only as a guide - a humble servant - and with gentleness you may nudge someone in a direction.

\section{Not as a merchant or salesman}

To witness to and guide towards a Christian worldview, one should never act like one who sells a commodity to be bought. However, this is exactly what is occurring today in secular, commercialised tertiary education the world over. Lecturers are regarded as producers and sellers of knowledge while students are called their clients. The buyers may purchase by picking as much or as little as they want to satisfy their existing desires, e.g. only to get a diploma or degree and then a well-paying job. A worldview is betrayed when it is sold - it is a free gift to be shared freely.

4.Worthwhile reading is offered by the following: Beale (2008), Goudzwaard (1984), Goudzwaard et al. (2007), Keller (2009), Haberthal and Avishai (1992, Meadors (2006), and Wilkens and Stanford (2009).

5.Zechariah 4:6 admonishes: 'This is the Word of the Lord: "Not by might, nor by power, but by my Spirit"'. It is God who has to work in both the giver and receiver: 'It is God who has to work in you to will and to act according to his good purpose' (Phlp 2:13; cf. also De Graaff 1966:161). 


\section{Not as a gadfly or midwife}

The ancient Greek philosopher Socrates thought that the way to approach his students was to question them - as a gadfly bites a horse - to get them thinking. His other image, that of a midwife, supposed that the appropriate knowledge to act was already hidden in his students, it was something already present in themselves of which he only had to remind them again.

However, many young people nowadays do not really know the content of God's revelation and the basics of a Christian worldview which would enable them to reshape it and render it relevant to new challenges. Personal experience with students also indicates that they do not know reliable authors and books on an integral Christian worldview tradition.

Most of the above three approaches will fail because they want to hand over a worldview from the outside, to prescribe or even dictate it. This goes in against the very nature of a view and way of life. It has to be freely chosen, tested for its trustworthiness and value in real life to be accepted.

For older people to accept this fact requires courage. It asks for the recognition of the fact that what they held to be good can actually be wrong or improved; what is immutable in their worldview can be changed. Therefore, the image of a mentor will be more appropriate.

\section{Mentoring as a key to sharing}

On the Internet one can find much information on what makes a good mentor. A mentor is described as an advisor, counsellor, guide, tutor and teacher who is knowledgeable and holds vast experience, which is open to share his experience in order to advance the growth of a younger person. A mentor should have the following qualities: caring, willing to spend time, patient, trustworthy, an active listener, inspirational, able to give practical advice and sensitive to people's feelings.

Applied to the transfering of a worldview, younger people have to see a mentor's worldview becoming flesh and blood in their own live. They must experience that they can trust the mentor and that it is possible and worthwhile to shape their own live according to a similar perspective on life.

\section{A key to intergenerational communication}

Van Belle (2012:48 ff.), a Christian psychologist, is only one of many who sees mentoring as a key to intergenerational communication. It should happen in mutual respect, since the generations need one another and have to complement each other. Children cannot grow up unless parents nurture them. But the opposite is also true: Parents cannot be parents unless they have children and adolescents to bring up. Van Belle (ibid) defines a mentoring relationship as follows:

A mentorship relationship is one which provides company for emerging adults, which shows respect and caring towards them, and which supports, challenges and inspires them in the context of on-going dialogue with them. (p. 49)
Important is, however, that mentorship should not be confined to individuals. What is needed is a mentoring community to support a younger generation. They need the security of a place where they really belong, where they feel at home (cf. 'A supportive community' below).

\section{Reverse mentoring}

Van Belle also emphasises that mentoring is not a one-way process where influence only flows in one direction: from the older to the younger. There should be reverse mentoring. Older adults may also be mentored by emerging adults. The younger person to whom one wants to transfer one's Christian worldview should not remain a passive receiver but also become a giver. Older people will really respect the young by seeing themselves as receivers too, to allow younger ones to enrich and reshape their own, often out of date worldviews.

Christian mentors have to guide their pupils, students, or mentees to a specific goal, in this case to the acceptance of a Christian worldview necessary for an own identity. They have to unfold God's entire creation for the receivers, enabling them to live in the world according to God's sovereign will for every aspect of their life (cf. Fowler et al. 1990:157-161.)

\section{Difficult to achieve today}

During the author's student years, he was not satisfied with 'mere Christianity', a thin, underdeveloped Christian worldview. He was blessed, however, with many excellent worldview mentors. (It was still possible since his academic mentors were committed to a Christian worldview and the total student population at the Potchefstroom University for Christian Higher Education was only about 1 500.) He can therefore imagine that a university which today has to cater for about 60000 students without the personal contact and influence of Christian mentoring lecturers and professors can be an arctic winter, a place of specialists, often inspired by non- and even anti-Christian spirits. However, if Christian lecturers are serious about their worldview, mentoring should not be regarded as idealistic.

The fourth main issue to be answered is coming up.

\section{What are the prerequisites for the effective sharing of a worldview with a younger generation?}

At the beginning of this article attention was asked to two basic aspects of a worldview, viz. the developmental and the historical. The first refers to how most young people are structured, what they look like and how they behave during their specific stage of development. One may call this the typical and more or less constant feature in every generation. The second is how the direction of life of the young differs from that of previous generations because it is influenced by the values or norms of a new cultural current. The first aspect will now be treated briefly, the second in more detail. 


\section{Knowledge about the stages of life}

How does one's religion-based worldview develops through the different seasons of life from early childhood, through adolescence, to emerging and mature adulthood and finally to old age? A great volume of literature answering this important question is available today. ${ }^{6}$

Worldview formation during an earlier stage, starting from about 13 and especially during adolescence, is usually turbulent and characterised as seeking, which has to end in an owned worldview and own identity from about 20 to 30 years (cf. Olthuis 1986:36-39). Adolescents usually experiment with all sorts of life options, directions or worldviews. Once they have made their choice, their lives become more stable; they have acquired an own identity. If this development does not occur then, serious implications may follow during the later stages of life.

It should again be emphasised that the older generation of parents, teachers, mentors, lecturers, and ministers can influence this development but cannot determine it. The Holy Spirit alone can achieve such a wonder. Older peoples' responsibility is limited to the activation, disclosure and deepening of the young person's religious commitment and worldview.

There are different practical ways of achieving this, for instance by reading and studying together God's Word, also by praying together, commemorating together important religious events, doing acts of faith together and talking and listening to each other. ${ }^{7}$

\section{Knowledge about generational differences}

The second requirement for worldview transfer is now treated in more detail.

\section{Emerging adults}

Today's younger generation (approximately from 18-30 years) are called emerging adults. It is a new stage identified in between the older distinction between adolescence and adulthood. This was done since new research indicated that today it takes much longer than in the case of previous generations to become a mature adult. In today's new cultural environment with its numerous choices offered, young women and men are more likely to continue their spiritual quest, their search for an own worldview and own identity for another decade up to even about thirty before they (perhaps) get married, start a family and settle into an adult life style.

As a result of different cultural-historical circumstances during these formative years, scholars from different disciplines have researched and divided Western populations 6.See, e.g. Van Belle 2016 and the extensive bibliography in Van der Walt 2007:41-46. 7.A valuable Bible study book to provide the biblical basis for a Christian worldview is Bartholomeo and Goheen (2004). For practical hints to inculcate a Christian view, cf. Van der Walt 2007:33-39. (according to date of birth) in about five different generations or cohorts, and applied their results in business, medical care, education, et cetera. These generations are: the Veterans (born between 1922 to 1943); the Baby Boomers (born from 1943-1960); Generation X (1960-1980); Generation Y, Generation Me, or the Millennials (1980-2000); the present Generation Z (born after 2000), also called the i-Generation.

\section{Generation Y, Me, or Millennials}

This article will not debate the validity of these distinctions but treat the last two groups as one group, calling them Generation Me. Many academics have already researched them in order to pinpoint their similarities but especially their differences and discontinuity with the preceding four generations. ${ }^{8}$

For this reconnaissance the writer, after consulting part of the growing literature, mainly focused on the book of one author, viz. Jean Twenge's Generation Me (2006) as well as some of her subsequent articles and critical reviews of her work. ${ }^{9}$

Firstly, Twenge (2006) combines Gen. Y and Z in one group, called Gen. Me. Secondly, she does not only offer critique but also indicates the positive traits of this generation. Thirdly, she dares to challenge other more optimistic portrayals of Gen. Me. According to her this generation reveals the increasing individualism (already predicted inter alia by Lasch 1979) of the American youth which can clearly be detected in their unfounded extreme self-focus, -esteem, -congratulation, entitlement and feeling good about themselves. Paradoxically simultaneously, because of too high expectations about themselves, they experience more anxiety and depression. Fourthly, Twenge was chosen as a guide since her research is based on research data provided by Gen. Me Americans themselves. Subsequent research in countries outside the US also confirmed most of her results. ${ }^{10}$

\section{Two questions}

At first, two questions should be answered. The first is whether one may apply the findings of the research conducted mainly in Western contexts like North America to one's own situation in South Africa.

On the one hand it may be done, because young South Africans also live in an increasingly globalising world, strongly influenced by Western and especially American capitalist consumer culture. This is evident from the research done on middle class white youth of the three Reformed denominations in South Africa (cf. Nel \& Van der Westhuizen 2015). On the other hand one should be careful to generalise, since not much information is available about the black youth of today (some information is provided by Qunta (ed.) 2016).

\footnotetext{
8.For a quick update, consult the 6-page Generational Differences Chart (Anon. n.d.) It provides the years of birth, the names of the generations, their core values, work ethics and more.

9.See, e.g. the bibliography of Burke and Cooper (2012) and Twenge (2014a; 2014b). 10.Cf. the dissertation by Ingeborg Kjaerstad (2014).
} 
The second question is about the danger of stereotyping in such an approach, leading to hasty conclusions and myths about vast differences between generations who all share the same human nature and are influenced by the same contemporary culture. Scholarly research tries to identify general trends amongst groups which would not necessarily apply to individual persons, often exceptions to the rule.

One may, for example ask whether the digital addiction to Facebook, Twitter, YouTube, MySpace, et cetera is only typical today of the latest iGeneration, profoundly shaped by Internet, iphone, ipad, et cetera (cf. 'Strongly influenced by information technology' below). Is it not in different degrees common throughout all generations and therefore does not say much about generational differences, but rather about the power of these technological gadgets?

Snyman (2013) wrote a parody on 1 Corinthians 13, from which a few (translated) sentences follow:

If I speak in the tongues of men and angels, but I don't have a cell phone, I am nothing ... Facebook is patient, Facebook is kind, it does not boast, it is not proud ... With Facebook and iPhone, I can keep record of wrongs and delight in evil ... I believe everything on BlackBerry ... it never fails. With iPod and iPhone, I know fully ... All that is left for me now is to wait and hope for new information ... (p. 67-79).

The tendency today in the electronic media is to package everything in attractive but easily digestible bits and pieces for consumption. Young people design their life perspective by cutting, pasting and mixing these 'nuggets'. Keeping this in mind, it may be advisable to share the Christian worldview not by presenting it as a system (not popular amongst the postmodern Gen. Me), but rather start with the problems in these nuggets, and from there gradually move to the answers provided by a broader worldview perspective.

However, it is difficult to decide which characteristics of Generation Me will foster and which will hamper worldview transfer. The same characteristic may in one sense render the receiving generation more receptive, while in another sense it may be an obstacle. Their pluralistic outlook, for example may be regarded as both positive (as openness to a Christian worldview) and negative (in favour of relativism). Instead of distinguishing between promoting and hampering traits, a few typical traits which may be of either positive or negative significance are given in the following section (cf. footnote 8 and Van Belle 2012:104 for a complete lists of Gen. Me's characteristics.)

\section{What are some of the typical characteristics of Generation Me ${ }^{11}$}

The following list is not nearly exhaustive, rather just a few examples. Some characteristics will also be explained in more detail, while others will only be listed. As will become evident, these characteristics are also closely related to one another. ${ }^{12}$ Lastly, if the following description sometimes tends to be negatively biased, it can probably be explained by the age of the present author.

\section{Individualism}

Some authors from the past and present already support Twenge's (2006) subsequent analysis. Walter (1979:60) writes that individualism is perhaps the most influential idea in Western thinking. It entails the worship of the so-called independent and free individual as an ultimate value, and the happiness of the individual as the sole aim of life. Not only is the meaning of life to be found by the individual, it can only be found within the self (p. 181). Previously meaning and identity was given by society, today it is chosen by the autonomous individual.

Lyon (2001:32) distinguishes between two types of contemporary individualism. On the one hand is expressive individualism, in which the self is central and where needs are met through experience, especially bodily ones. On the other hand, in acquisitive individualism, in which consuming is central, choice is paramount. (Cf. also Conradie 2010.) Both types are discernible in Generation Me.

These kinds of individualism lead to what is called a 'plastic self' (Lyon 2001). Selfhood becomes a postmodern project:

For some ... the self is the outcome of consumer choices in which symbols such as brand names and merchandising logo's feature strongly. For others, the self is part of therapeutic regimes or a quest for intimacy. For cybernauts, the self is construed as the digital personae developed within electronic communication. Either way, identity is not so much given - by family name or the image of God - or ascribed, as produced, the result of a continuing process of discovery. (p. 69)

According to a Christian worldview, however, the individual person is not unimportant but should not become the supreme norm (cf. Mouw 1988:63). Keller (2008) gives a similar description of contemporary individualism:

\footnotetext{
... individuals must be free to pursue their own goals and selfactualization regardless of custom and convention. In this view the world would be a far better place if tradition, prejudice, hierarchical authority and other barriers to personal freedom were weakened or removed ... I am the only one who can decide what is right or wrong for me. I am going to live as I want to live and find my true self and happiness that way. (p. 35, 36)
}

It may be precisely because of their individualist hearts that Gen. Me's are at the same time longing for fellowship. Otherwise it would be difficult to understand the Generational Differences Chart (cf. footnote 8) which indicates that they are independent and self-absorbed as well as sociable and grouporiented.

12.Especially two of them have been discussed extensively, viz. Generation Me's narcissism and the influence of Internet technology and digital media. See, e.g. narcissism and the influence of Internet technology and digital media. See, e.g.
Kjaerstad's dissertation (2014) which provides a bibliography on the most recent research. 


\section{Emphasis on the present}

Another characteristic of contemporary young people is their view of time (cf. Lyon 2001:120 ff.). Time (divided into past, present and future) is telescoped or compressed into the present, the instant, and the now. One may call it an extended present.

Note the implications: If the present devours the future, responsibility dwindles. And when the present devours the past, tradition will be negligible. Such an idea of 'timeless time' can also result in people having no real time for others. Life-long relationships, like marriages, may be equally dubious. The episodic, the fleeting, the uncertain then characterise social life in more and more spheres.

\section{Homelessness}

Van Belle (2012:10-12) views the main characteristic of Gen. Me's as their in between or homeless nature, the fact that they are still looking - with much uncertainty - for an own identity. They are constantly going somewhere, but without the certainty that they will ever arrive. For them the old worldview forms rattle but the new delay to appear. They were born too late for the old and too early for the new.

This may, by the way, explain why many young people between their teens and twenties are today recruited by ISIS for acts of violence. They do not necessarily suffer from mental illness, brainwashing, political propaganda or negative social conditions like oppression and poverty. Many of these suicide bombers are normal youngsters from middle class Western families. And few of those over thirty are recruited by ISIS and other radical Islamic groups. Not to be sure about the direction of one's life and one's own identity in today's multireligious, multicultural world can be unbearable for emerging adults, while these Islamic factions demand total, unthinking loyalty, no questions asked. They pressurise young men and women to make a choice right now, offer them an easy way to certainty - there is only one way to believe and behave.

\section{Strongly influenced by information technology}

Most authors agree that Gen. Me is highly involved in and influenced by information technology, continuously surfing the net for quick information. Rather than reading books, they skim and scan quick information, opt for virtual communication, spending much time on social networking.

What Toffler (1980) predicted in the eighties became a reality today. After the agricultural and industrial revolution, we have entered an information revolution. Lyon (1990:195) wrote a decade later that especially the young are not only daily involved in the digital world, but contemporary information technology is redefining their image of being human.

Since the digital world is not bias-free, it plays a central role in how people see themselves and the world around them. The priorities of those in charge of all kinds of media enable them to filter out information and portray life according to their own version. Decades ago already Walter (1979:141) warned that the notion of unbiased information is perhaps more dangerous than the censorship and conscious propaganda of totalitarian states. In such states the populace may at least realise that what they are getting is selective propaganda, and that there are alternative definitions of being human and of reality, even if they are not allowed to be mentioned.

At the same time today's digital world includes many advantages. One should therefore be careful not to portray a one-sided negative view of contemporary media. Van der Stoep (2011) provides a balanced evaluation. ${ }^{13}$

\section{A pluralistic outlook}

Gen. Me is pluralistic in outlook, open for value diversity, interaction and inclusion, in favour of dialogue and tolerance. Lyon (2001:94) again puts it succinctly, 'Belief is demoted, experience promoted, divisive doctrine diminished, a unifying stress on spirituality magnified ... self religion is central.'

Elsewhere Lyon calls this an a la carte religion and worldview. And Taylor (2008:29) writes that spirituality is the religion of our postsecular times. Both Lyon (2001:9) and in greater detail Taylor (2008) further describes this new kind of religion as a commodified or commercialised worldview in which entertainment and feeling good rather than obedience is important. Clearly Gen. Me is postmodern to the core. ${ }^{14}$

During the last three decades the phenomenon called (new) 'spirituality' was propagated from various perspectives in a flood of publications. It ranges from Christian to revived pagan spirituality, ties in with already mentioned characteristics of the contemporary youth, strongly influence them today and need to be carefully evaluated from a Christian perspective as in Van der Stoep et al. (2007).

\section{Distrustful}

The latest generations distrust systems, authority, power, institutions and inflexible hierarchical organisations. They prefer personal expression, authenticity and personal experience. At the same time - in spite of their age - they respect strong ethical leaders, understand the importance of great mentors and expect their bosses to mentor them in the attainment of their goals.

\section{Achievement-oriented}

According to Burke and Cooper (2012:127) although members of Gen. Me are achievement-oriented, emphasising material rewards, and prefer meaningful work, they are not willing to

13.Further studies to be consulted are: Cavalier (ed. 2005), Tascott (2009), Turkle (2011). Schuurman (2013) provides an explicit Christian worldview perspective on digital world.

14.A large part of Van Belle (2012:59-81) is therefore devoted to a valuable overview of Western intellectual history and the development of Postmodernism. Cf. also of Western intellectual history and the development of Postmodernism. Cf. also
Middleton and Walsh (1995) for a Christian evaluation of postmodern thinking and living. 
work hard for the rewards they desire. This phenomenon ties in with today's consumer-directed capitalist economy, which creates not only a culture of desire, but also a new image of being human. From a Christian perspective Bell (2012:93122) questions this contemporary economistic view of what it means to be human.

\section{High expectations}

A last feature is that young people like to try new things, are willing to change their minds, believe everything is up for grabs, and have perhaps too high expectations about themselves and their future.

The sixth and last question is still to be answered.

\section{How should a worldview tradition be received by a younger generation?}

Even with the amount of knowledge we today have about Gen. Me, it will still be difficult to predict how they may receive an integral Christian-reformational worldview to guide their way of life. The following remarks are focused on how it should happen.

Two characteristics of a tradition should, however, be kept in mind. On the one hand, the young representatives within a tradition look at the past; orient themselves to a certain previous authority or source of inspiration. On the other hand, they live in the present and look at the future.

There are at least four ways in which a tradition should be received (cf. also Wolterstorff 1987).

\section{Openness}

Firstly, every new generation of Christians should be openminded to an older tradition as a gift. The ideal is - even for someone who has eventually discarded a tradition to improve on the failures of the past - that the existing worldview should serve as a starting-point.

\section{Critique of the old}

The second step is critique, sympathetic critique, but critique nevertheless. Critical questions like the following should be asked: Does this worldview offer a valid interpretation of the world of today? Does the inherited worldview open the possibility of an authentic way of life and of an own identity? Does it provide meaning?

Such critique is necessary for two reasons. In the first place, even the shaping of a Christian worldview will always remain unfinished business. As said previously, the biblical demand is continuous reformation.

The second reason is that history, especially in the contemporary dynamic ever-changing environment, is moving on.
Vollenhoven (2005b:153-156) indicates how, during Western cultural history, new normative currents continuously appeared, outdating previous ones. The implication is that every new generation of Christians has the task to apply God's central command of love in new, relevant ways in the different domains of life. If this is not done, Christians are simply lazy traditionalists, escaping their responsibility.

Perhaps the following warning of Christ not only applies to a new birth at conversion, but may also be applied in the present context:

He warned in Luke 5:36-38:

No one tears a patch from a new garment and sews it on an old one. If he does, he will have torn the new garment, and the patch from the new will not match the old.

And no one pours new wine into old wineskins. If he does, the new wine will burst the skins, the wine will run out and the wineskins will be ruined.

No, new wine must be poured into new wineskins.

One cannot drive forward safely without watching in one's small rear view mirror what is behind you - the past is important. But your much larger windshield for looking ahead is more important. Christ admonishes: 'No one who puts his hand to the plough and looks back is fit for service in the kingdom of God' (Le 9:62).

\section{Creative reinterpretation and reshaping}

Adolescents and emerging adults start with how little or how much they have learned from their parents, peers and other mentors. It may be called their preliminary or thetic position or worldview. From this point of departure they will (against the contemporary cultural-historical context) in a critical way test the viability and meaningfulness of what they have inherited. Such a thetical-critical approach will have a double profit. On the one hand it may reinforce their preliminary worldview position, while on the other hand it provides a justifiable rejection of what is inconsistent with it in their new cultural context.

\section{A supportive community}

At the beginning it was mentioned that a worldview is usually developed within a community, as it is social in character. Emerging Christian adults will therefore not be able to take the above mentioned three important steps on their own or individually, as mentioned by Graber (1996:149): 'The influence of ideas has to be there, but the application is very hard to work out by yourself ... so you work it out within a group.'

\section{Elsewhere Garber (1996) also writes:}

Community is the context for the growth of conviction and character. What we believe about life and the world becomes plausible as we see it lived out all around us ... we discover who we are - and who we are meant to be - face to face and side by side with others in work, love and learning. (pp. 146-147) 
Such a wider worldview community should include the older generation. They should trust the younger ones to do better than they themselves could.

\section{A final word}

To succeed as sharers and receivers the following should never be forgotten: All of us are God's fellow workers (1 Cor 3:9). God works in the old and in the young; He works with and through both generations - sometimes in spite of one or both of them.

But in the final analysis the old and young can neither give nor receive without the Holy Spirit. Only He can open eyes and provide growth. Without God's blessing all initiatives will not have the desired results. However, his work never cancels our human responsibility.

\section{Conclusion}

Firstly, a brief summary and then a reminder will be given.

\section{Summary}

Because of the general cultural environment as well as the needs of a large generation of emerging adults this reconnaissance indicated the urgent need for a genuine, integral Christian worldview. It was indicated how such a precious liberating view could be shared with a younger generation as well as how it should be received.

\section{A reminder}

Different generations of Christians have to witness to each other, not merely for the sake of themselves but to be able to obey Jesus Christ's last command according to Acts 1:8b: '... You will be My witnesses ... to the ends of the earth.' His instruction should not be limited to sharing the good news in mission and evangelisation. It also includes the responsibility of sharing a Christian worldview with one's grandchildren, pupils and students. To fulfil this high and today often difficult calling, Christ's promise still holds: 'All authority in heaven and earth has been given to me ... And surely I will be with you always, to the very end of the age' (Mt 28:20b).

\section{Acknowledgements Competing interests}

The authors declare that they have no financial or personal relationships which may have inappropriately influenced them in writing this article.

\section{References}

Aay, H. \& Griffioen, S., 1998, Geography and worldview: A Christian reconnaissance, University Press of America, Lanham.

Anon., n.d., Generational Differences Chart, viewed 14 February 2017, from http:// www.wmfc.org/uploads/GenerationalDifferencesChart.pdf

Bartholomew, C.G. \& Goheen, M., 2004, The drama of Scripture: Finding our place in biblical history, Baker, Grand Rapids.
Bartholomew, C.G. \& Goheen, M., 2013, Christian philosophy: A systematic and narrative introduction, Baker Academic, Grand Rapids.

Bavinck, H., 1913, Christelijke wereldbeschouwing, Kok, Kampen.

Bavinck, J.H., 1981, The church between the temple and the mosque, Eerdmans, Grand Rapids.

Bavinck, J.H., 2013, The J.H. Bavinck reader, ed. J.H. Bolt, Eerdmans, Michigan.

Beale, G.K., 2008, We become what we worship: A biblical theology of idolatry, InterVarsity, Downers Grove.

Bell, D.M., 2012, The economy of desire: Christianity and capitalism in a postmodern world, Baker Academic, Grand Rapids.

Bonzo, J.M., \& Stevens, M. (eds.), 2009, After worldview: Christian higher education in a postmodern world, Dordt College Press, Sioux Center.

Buijs, G.J., 2012, 'Worldview, the credit crisis and the "unity of life": From "famework" to "deep commitment"', Koers 71(1), 29-38. https://doi.org/10.4102/koers. v77i1.186

Burke, R.J. \& Cooper, C.L. (eds.), 2015, The multi-generational and aging workforce, Edward Edgar Publishing, Northampton.

Cavalier, R.J. (ed.), 2005, The impact of the Internet on our moral values, State University of New York Press, Albany.

Conradie, E., 2010, Christianity and a critique of consumerism, Bible Media, Wellington.

De Graaff, A.H., 1966, The educational ministry of the church, Verenigde Drukkerij Judels \& Brinkman, Delft.

Fowler, S., Van Brummelen, H.W. \& Van Dyk, J., 1990, Christian schooling, education for freedom, Institute for Reformational Studies, Potchefstroom.

Garber, S., 1996, The fabric of faithfulness: Weaving together belief and behaviour during the university years, InterVarsity, Downers Grove.

Goudzwaard, B., 1984, Idols of our time, Dordt College Press, Sioux Center.

Goudzwaard, B., Van der Vennen, M. \& Van Heemst, D., 2007, Hope in troubled times, Baker Academic, Grand Rapids.

Griffioen, S., 2012, 'On worldviews', Philosophia Reformata 77(1), 19-56. https://doi. org/10.1163/22116117-90000521

Habertal, M. \& Avishai, M., 1992, Idolatry, Harvard University Press, Cambridge.

Hengstmengel, B., 2015, Denken met het hart: Christelijke filosofie in de traditie van Augustinus en Calvijn, Buijten \& Schipperheijn, Amsterdam.

Heslam, P.S., 1998, Creating a Christian worldview: Abraham Kuyper's lectures on Calvinism, Eerdmans, Grand Rapids.

Keller, T., 2008, The prodigal God: Discovering the heart of the Christian faith, Riverhead Books, New York.

Keller, T., 2009, Counterfeit Gods: The empty promises of money, sex, power and the only hope that matters, Riverhead Books, New York.

Kjaerstad, I., 2014, iGeneration or Generation Me? Identity development with the Millennials, Dissertation, Department of Communication, Bond University, Australia, viewed 14 February 2017, from https://ingeborgkjaerstad.wordpress. $\mathrm{com} / 2014 / 12 / 06 /$ igeneration-or-generation-me-identity-development-with-themillennials

Lasch, C., 1979, The culture of narcissism, Norton, New York.

Lyon, D., 1990, 'Assessing the information society concept', in S. Griffioen \& J.P. Verhoogt (eds.), Norm and context in the Social Sciences, pp. 183-198, University Press of America, Lanham.

Lyon, D., 2001, Jesus in Disneyland: Religion in postmodern times, Polity Press, Cambridge.

Meadors, E.P., 2006, Idolatry and the hardening of the heart: A study in biblical theology, Clark, London.

Mouw, R.J., 1988, 'Reflections on individualism', in P.A. Marshall \& R.E. VanderVennen (eds.), Social Science in Christian perspective, pp. 63-81, University Press of America, New York.

Naugle, D.K., 2002, Worldview: The history of a concept, Eerdmans, Grand Rapids.

Nel, M. \& Van der Westhuizen, Z. (reds.), 2015, Skokkend positief: Insigte vanuit nuwe navorsing oor aktiewe Afrikaanse kerkjeug, Bybelkor, Wellington.

Oden, T.C., 2007, How Africa shaped the Christian mind: Discovering the seedbed of Western Christianity, IVP Books, Downers Grove.

Olthuis, J.H., 1986, Keeping our troth: Staying in love through the five stages of marriage, Harper \& Row, San Francisco.

Olthuis, J.H., 2012, 'A vision for love: Towards a Christian post-modern worldview', Koers 71(1), 46-55. https://doi.org/10.4102/koers.v77i1.28

Qunta, J. (ed.), 2016, Writing what we like: A new generation speaks, Tafelberg, Kaapstad.

Schuurman, D.C., 2013, Shaping a digital world: Faith, culture and computer technology, IVP Academic, Downers Grove.

Snyman, D., 2013, Onder die radar, Tafelberg, Kaapstad.

Tascott, D., 2009, Grown up digital, McGraw-Hill, Toronto.

Taylor, B., 2008, Entertainment theology: New-edge spirituality in a digital democracy, Baker Academic, Grand Rapids.

Toffler, A., 1980, The third wave, Pan, London. 
Turkle, S., 2011, Alone together: Why we expect more from technology and less from each other, Basic Books, New York.

Twenge, J.M., 2006, Generation Me, Free Press, New York.

Twenge, J.M., 2014a, Generation Me, viewed 14 February 2017, from http://www. generationme.org/reviews/html

Twenge, J.M., 2014b, Generation Me, viewed 14 February 2017, from http://www. generationme.org/about-book.html

Van Belle, H.A., 2012, Integration lost and found: Why suits and skirts don't talk with jeans, why they should, and how they can, Legacy Press, Edmonton.

Van Belle, H.A., 2016, 'Different unpublished articles on the development of personality during the life course, the development of lived religion, walking through the seasons of life, etc.' (Available from the author at harryvanbelle@ hotmail.com)

Van der Hoeven, J., 1980, Peilingen, Buiten \& Schipperheijn, Amsterdam.

Van der Stoep, J., 2011, 'Media en communicatie', Sophie 2, 19-21.

Van der Stoep, J., Kuiper, R. \& Ramaker, T. (reds.), 2007, Alles wat je hart begeert Christelijke oriëntatie in een op beleving gerichte cultuur, Buijten \& Schipperhijn Amsterdam.

Van der Walt, B.J. (red.), 1980, Die inslag van die Calvinisme in Suid-Afrika, 4 dele, PU vir $\mathrm{CHO}$, Potchefstroom.
Van der Walt, B.J., 2007, 'Growing together in faith: How can it be understood theoretically and be achieved practically?' in B.J. van der Walt, Transforming power, pp. 11-46, Institute for Contemporary Christianity in Africa (ICCA) power, $\mathrm{pp}$. 11
Potchefstroom.

Van der Walt, B.J., 2008, The eye is the lamp of the body: Worldviews and their impact, Institute for Contemporary Christianity in Africa (ICCA), Potchefstroom.

Van der Walt, B.J., 2010, At home in God's world, Institute for Contemporary Christianity in Africa (ICCA), Potchefstroom.

Volf, M., 2011, A public faith: How followers of Christ should serve the common good, Brazos Press, Grand Rapids.

Vollenhoven, D.H. Th., 2005, The problem-historical method and the history of philosophy, K.A. Bril (ed.), De Zaak Haes, Amstelveen.

Walter, J.A., 1979, A long way from home, Paternoster Press, Exeter.

Wilkens, S. \& Sanford, M.L., 2009, Hidden worldviews: Eight cultural stories that shape our lives, InterVarsity Academic, Downers Grove.

Wolters, A.M., 1981, 'Facing the perplexing history of philosophy', Journal for Christian Scholarship 17(4), 1-31.

Wolters, A.M., 2005, Creation regained: Biblical basics for a reformational worldview, Eerdmans, Grand Rapids.

Wolterstorff, N., 1987, Keeping faith: Talks for new faculty at Calvin College, Calvin College Press, Grand Rapids. 